\title{
CSR communication, corporate reputation, and the role of the news media as an agenda setter in the digital age
}

Vogler, Daniel ; Eisenegger, Mark

\begin{abstract}
By using social media, corporations can communicate about their corporate social responsibility (CSR) to the public without having to pass through the gatekeeping function of the news media. However, to what extent can corporations influence the public's evaluation of their CSR activities with social media activities and if the legacy news media still act as the primary agenda setters when it comes to corporate reputation have not yet been thoroughly analyzed in a digitized media environment. This study addressed this research gap by looking at the effect of CSR communication through Facebook and news media coverage of CSR on corporate reputation in Switzerland. The results of this longitudinal study show that the salience and tone of news media coverage of CSR were positively related to corporate reputation, even though the news media coverage about CSR was predominantly negative. Thus, reputation was still strengthened even in the face of negative publicity. No effect of CSR communication through Facebook on corporate reputation was found. The results suggest that legacy news media still were influential in determining how the public evaluates corporations in the digital age.
\end{abstract}

DOI: https://doi.org/10.1177/0007650320928969

Posted at the Zurich Open Repository and Archive, University of Zurich

ZORA URL: https://doi.org/10.5167/uzh-196277

Journal Article

Accepted Version

Originally published at:

Vogler, Daniel; Eisenegger, Mark (2021). CSR communication, corporate reputation, and the role of the news media as an agenda setter in the digital age. Business Society, 60(8):1957-1986.

DOI: https://doi.org/10.1177/0007650320928969 


\title{
CSR Communication, Corporate Reputation, and the Role of the News Media as an Agenda-Setter in the Digital Age
}

\section{Daniel Vogler' (iD) and Mark Eisenegger'}

\begin{abstract}
By using social media, corporations can communicate about their corporate social responsibility (CSR) to the public without having to pass through the gatekeeping function of the news media. However, to what extent can corporations influence the public's evaluation of their CSR activities with social media activities and if the legacy news media still act as the primary agenda setters when it comes to corporate reputation have not yet been thoroughly analyzed in a digitized media environment. This study addressed this research gap by looking at the effect of CSR communication through Facebook and news media coverage of CSR on corporate reputation in Switzerland. The results of this longitudinal study show that the salience and tone of news media coverage of CSR were positively related to corporate reputation, even though the news media coverage about CSR was predominantly negative. Thus, reputation was still strengthened even in the face of negative publicity. No effect of CSR communication through Facebook on corporate reputation was found. The results suggest that legacy news media still were influential in determining how the public evaluates corporations in the digital age.
\end{abstract}

'University of Zurich, Zurich, Switzerland

\section{Corresponding Author:}

Daniel Vogler, Research Center for the Public Sphere and Society, University of Zurich,

Andreasstrasse 15, Zurich 8050, Switzerland.

Email: daniel.vogler@foeg.uzh.ch 


\section{Keywords}

agenda setting, corporate reputation, CS communication, Facebook, news media, social media

Corporate social responsibility (CSR) has become an established part of the strategic communication of corporations as "citizens are increasingly demanding that the corporations justify and legitimate not only their economic actions, but also their social and environmental actions in the general public sphere" (Colleoni, 2013, p. 229). Being socially responsible has been shown to have a positive effect on the behavior of a corporation's various stakeholders such as consumers, investors, and employees (for an overview, see Peloza \& Shang, 2011; Pérez, 2015). However, the business returns to CSR are dependent on stakeholders' awareness of a company's CSR activities (Du et al., 2010). Communication about CSR has thus been seen as a defining element of corporate CSR activities (Crane \& Glozer, 2016; Morsing $\&$ Schultz, 2006; Schoeneborn et al., 2019). Consequently, CSR communication is typically aimed at highlighting the positive achievements of a corporation concerning environmental, economic, and social responsibility. However, when corporations do not live up to their self-promoted social standards and do not meet the expectations of their stakeholders, severe damage can be done to their reputations (Breitinger \& Bonardi, 2017; Eisenegger \& Schranz, 2011). Consequently, scholars have discussed whether communicating about CSR might involve a reputational risk (Morsing \& Schultz, 2006; Schultz \& Wehmeier, 2010).

Given that the news media have demonstrated the ability to set the public agenda (McCombs et al., 1997; McCombs \& Shaw, 1972), they are also likely to influence which companies are perceived as relevant by the public and how the public evaluates these companies (Carroll \& McCombs, 2003). In the formation of corporate reputation, which is defined as the evaluation of a corporation by its stakeholders (Fombrun \& van Riel, 2003), the news media are thus considered as highly important (Carroll \& McCombs, 2003; Deephouse, 2000; Eisenegger et al., 2010). Whether a corporation's CSR activities are covered positively or not will correspondingly influence its reputation (Einwiller et al., 2010). However, digitization is rapidly changing the communicative environment for corporations, and new communication channels challenge the traditional role of the news media as the primary agenda setters. This includes the influence of the media in shaping the reputation of corporations (Etter et al., 2019). "Today, the media environment is far more diverse, fragmented, and polycentric, and new practices have developed out of the rise of digital communication" (Chadwick, 2017, p. 24). 
Chadwick's diagnosis of political communication in so-called hybrid media systems is also true for corporate communication practices. One of the most important aspects of the transformation of the media environment is that the organizations can now reach potentially large audiences without having to pass through the gatekeeping function of the news media (Wallace, 2018). With social media at hand, corporations can communicate directly about their CSR to different stakeholders, which leads to changing communicative dynamics between the corporations and their environment (Kent \& Taylor, 2016; Schultz et al., 2013). Scholars have thus started to analyze the effects of corporate social media activities on different stakeholder groups and the general public to investigate whether social media provide corporations with capabilities to set the public agenda. Most of the research, however, has focused on individual social media channels and has rarely taken comparisons with legacy media into account (for an exception, see S. Y. Lee, 2016).

This longitudinal study investigated the effects of news media coverage of CSR and CSR communication of companies through Facebook on corporate reputation in Switzerland. It, therefore, looked at the agenda-setting effects of the news media and corporate social media activities on the public. The study linked three extensive data sets that covered the period from January 2011 to January 2018. The final data set included data from a manual content analysis of news media, an automated content analysis of posts from corporate Facebook pages, and an annual representative reputation survey. First, the study analyzed the effects of the tone in news media coverage of CSR on corporate reputation. Hence, we tested a hypothesis as suggested by Carroll and McCombs (2003), who postulated that the more positive the news media coverage was for an attribute of a corporation (in this case CSR), the more positively the members of the public will perceive that attribute. We also tested whether the mere salience of CSR in news media coverage influences corporate reputation in a positive way. Next, we tested the agenda-setting capabilities of corporate social media activities by analyzing whether the salience of CSR on corporate Facebook pages and user reactions to CSRrelated posts were positively related to corporate reputation. The results showed that the salience and tone in the news media coverage of CSR were positively related to corporate reputation. In contrast, no direct effects of CSR communication through Facebook on corporate reputation were found. The findings of this study indicated that corporations only had a limited social media-based influence on how the public evaluated their CSR activities and that the news media still played an essential role in the production, dissemination, and evaluation of information about corporate CSR activities. It also provides further insights into the so-called CSR paradox (Morsing et al., 2008) as the study showed that despite the media coverage being 
predominantly negative, a positive correlation between the media coverage and reputation existed.

\section{Theory and Hypotheses}

\section{CSR and Corporate Reputation}

Numerous studies have shown a positive effect of CSR on corporate reputation, which is defined as the evaluation of a corporation by its stakeholders (Fombrun \& van Riel, 2003). They have spoken of CSR as a reputation in advance (Klein \& Dawar, 2004) or as self-insurance against reputation risks (Minor \& Morgan, 2011). Schnietz and Epstein (2005) discovered that a corporation's positive CSR reputation could act as a reservoir of goodwill in crises, protecting the corporation from experiencing stock price declines. Similarly, Y. Kim and Woo (2019) concluded that "a company with positive CSR reputation experiences no decrease in its CSR reputation during victim crises and fairly minor decreases during preventable crises" (p. 21). However, other studies have referred to the communication of CSR activities as a reputational risk. According to a study by the Reputation Institute (2017), Dutch corporations scored lower with regard to their CSR than on other reputation attributes. The authors concluded that there was a gap between the actual and perceived CSR of the examined corporations. The perception of CSR by the public is, therefore, not necessarily in line with the efforts and activities of a corporation. Morsing and colleagues (2008) wrote about the CSR paradox: The public expects corporations to take responsibility, but when corporations speak about responsibility, skepticism arises. Eisenegger and Schranz (2011) identified the criteria of mass media news selection, which is often focused on negativity, as the main cause of the CSR paradox. The news media not only covered the positive aspects of CSR, which corporations wanted them to report on, but they also covered the negative aspects of CSR, for example, environmental pollution or violation of corporate governance guidelines.

Mixed results have been found in studies that have examined the tone in news media coverage of CSR with some showing a predominantly positive tone (Byun \& Oh, 2018; Cahan et al., 2015; T. H. Lee \& Riffe, 2017) and others a more negative tone (S. Y. Lee \& Carroll, 2011; Luo et al., 2011; Vogler \& Gisler, 2016). T. H. Lee and Riffe (2017) found a positive tone toward referenced corporations in relation to CSR in coverage of The Wall Street Journal and The Financial Times. In their study, they also showed that the U.K.-based Financial Times exhibited a significantly higher ratio of positive tone toward the referenced corporations than its U.S.-based counterpart. However, especially business media often "present CSR as a business case 
rather than as something the society could benefit from" (Grafström \& Windell, 2011, p. 235). Research has indicated that "corporations are not necessarily the most influential voice in CSR and that other groups [e.g., NGOs] also have their views represented in the news media" (Tam, 2019). Consequently, S. Y. Lee and Carroll (2011) demonstrated an augmentation of the negative valence in media coverage of CSR between 1980 and 2004 in their longitudinal study. Vogler and Gisler (2016) came to a similar conclusion in their work on the Swiss banking industry during the financial crisis of 2008 as the banks' CSR was mostly covered in a negative tone.

Overall, the existing literature has led to a diagnosis that CSR is a rather contested corporate attribute with different actors trying to gain interpretive dominance. The news media are still generally considered as a place where people learn about topics of societal relevance. CSR-related information in the news media is therefore considered to influence the way people evaluate a corporation; in other words, the news media set the CSR agenda for the public. However, as corporations have started to use different social media to reach their stakeholders, the question arises whether corporations can set the public agenda through their own social media channels. In the following sections, the agenda-setting effects of the legacy news media and social media are conceptualized, and corresponding hypotheses are presented.

\section{Agenda-Setting of the Legacy News Media}

The main hypothesis of agenda-setting theory is that the media have an influence on which topics people think are relevant or important. The theory was developed and introduced half a century ago by McCombs and Shaw (1972). Since then, it has produced an abundance of theoretical and empirical work and has undergone various adaptions. Especially notable among them is the distinction of second-level or attribute agenda-setting (Carroll \& McCombs, 2003; McCombs et al., 1997), meaning that media not only influence what the public perceives as relevant but also how the public thinks about a topic or certain of its attributes.

Agenda-setting theory was developed, theorized, and tested primarily in the field of political communication. As such, public opinion on political issues (Palmgreen \& Clarke, 1977; Wirth et al., 2010) and on political parties or candidates running for election (Kiousis et al., 2006; McCombs et al., 1997) can be found at the center of this research. However, Carroll and McCombs (2003) have pointed out that the general theoretical ideas of firstand second-level agenda-setting fit equally well in the world of business communication. By making organizations more salient in their coverage, the news media increase the public salience of those organizations (the first level 
of agenda-setting). By emphasizing certain attributes of organizations and ignoring others, the news media also influence how the public evaluates these organizations (the second level of agenda-setting). Attributes are defined as the various traits that constitute the image of an object, in this case, of an organization. Regarding attributes, Carroll and McCombs (2003) distinguished between a substantive and an evaluative dimension. Examples of the substantive attributes of a corporation are its performance, management, and CSR. Substantive attributes are linked to different evaluative attributes in the news media, typically positive, negative, neutral or mixed evaluations. In media coverage, substantive and evaluative attributes are combined and then, according to the second level of agenda-setting, lead to similar or identical patterns of evaluations of organizational attributes by the public (Carroll \& McCombs, 2003).

The general assumptions of agenda-setting theory in a business context have been supported by empirical work (Eisenegger et al., 2010; Hester \& Gibson, 2003; Meijer \& Kleinnijenhuis, 2006b; Ragas, 2013). Some studies have also looked at CSR from an agenda-setting perspective. Esrock and Leichty (1998) analyzed how corporations use websites to set the public agenda and to present themselves as socially responsible citizens. They found that $82 \%$ of Fortune 500 companies had already addressed at least one CSR issue on their website in 1998. In their study on the public disclosure of environmental performance information, Brown and Deegan (1998) demonstrated that "the media can be particularly effective in driving the community's concern about the environmental performance of particular organizations" (p. 21). Pollach (2013) showed that corporate and public environmental agendas mirrored each other and that the corporate agenda was set by the media for some issues but not vice versa.

We defined CSR as a substantive attribute of a corporation, which was linked to different evaluative attributes in the news media coverage. Based on the general assumption of the second level of agenda-setting, we assumed that the way the media cover the CSR activities of a corporation influences how the public perceives it and ultimately will influence its reputation. This relation has been shown for a student population by Einwiller and colleagues (2010), who found a positive effect of news coverage tone of a firm's social and environmental responsibility on corporate reputation. We also expected that the higher the salience of a firm's CSR in the media coverage, the more positive the corporate reputation would be, an effect which was previously demonstrated to be true for global corporations (S. Y. Lee, 2016). For the effects of the tone and salience of news media coverage, we thus formulated the following hypotheses: 
Hypothesis 1.1: The more positive the tone in the news media coverage of the CSR activities of a corporation, the more positive its reputation will be. Hypothesis 1.2: The higher the salience of the CSR activities of a corporation in the news media coverage, the more positive its reputation will be.

\section{Agenda-Setting Through Social Media}

Agenda-setting theory and its main assumptions have been challenged by the digitization of the media environment (Takeshita, 2006; Williams \& Delli Carpini, 2004). Hence, the scholars of agenda-setting began studying the effects of digitalized media early on by examining elements, such as the effect of the internet in general (Roberts et al., 2002), corporate websites (Esrock \& Leichty, 1998), online news (Althaus \& Tweksbury, 2002; Lim, 2006), blogs (Meraz, 2009; Wallsten, 2007), search engines (B. Lee et al., 2015), and more recently, social media (Feezell, 2018; Neuman et al., 2014; Sayre et al., 2010).

Although the question of who sets the agenda in the digitized media arena is of high relevance, empirical evidence on how social media can set the agenda of the broader public is still rare. There is especially little comparative research on the capability of social media and legacy news media in setting the public agenda (for an exception, see Neuman et al., 2014; with regard to CSR, S. Y. Lee, 2016). At first glance, one would say that social media allow corporations to communicate directly to the audience or their stakeholders, which in turn questions the role of the traditional media in the process of agenda-setting. However, platforms such as Facebook are not neutral distributors of information in which the sender is able to reach individuals directly with content. Instead, content is filtered and distributed by algorithms based on rules that are usually not made completely transparent (Wallace, 2018), which is especially true for Facebook (DeVito, 2017). This algorithmic distribution based on user data presumably has two main consequences regarding agenda-setting. First, not all content will have the same probability of finding an audience. Research has shown that the topic of news is of relevance in reaching an audience through Facebook, for instance, soft news was preferred over hard news in one examination (Bakshy et al., 2015). Second, not all individuals that use a social media channel will be presented with the same agenda in their news feed on Facebook (Cardenal et al., 2018). This might lead to more fragmented audiences, especially when compared with legacy media (Feezell, 2018). Whether social media can be used by corporations as an instrument to reach their stakeholders directly and in a more controllable way is at least questionable. 
Several issues can be raised to question the capability of corporations in using their social media activities to set the public agenda. On the contrary, social media have clearly gained importance on the demand as well as on the supply side of news about corporations. An increasing share of people get their news through social media or even use it as a primary news source (Reuters Institute for the Study of Journalism, 2019). For most companies, social media have become an established part of their communication activities and are increasingly used for communicating with different stakeholder groups (S. Y. Lee, 2016). A central assumption of this article is that the firstand second-level agenda-setting hypotheses should also be applicable to social media activities by corporations. By communicating with the public through social media, the companies can raise their own salience with the public. By highlighting certain attributes in their social media communication, for instance, CSR, a company can influence how the public evaluates it.

\section{CSR Communication on Social Media}

Corporations will not only engage in CSR activities and let the media cover them as in the past, but to a larger extent, they will also actively try to promote them. It seems obvious that activities can shape the evaluation of the corporation by the public (i.e., their reputation) only if people are aware of them. Thus, "communication with stakeholders forms an essential element in the design, implementation, and success of corporate social responsibility" (Crane \& Glozer, 2016, p. 1,223). However, communication not only includes the production and dissemination of information about CSR, but instead, it is itself considered as an integral part of a corporation's CSR. For instance, Schultz and colleagues(2013) regarded CSR as communicatively constructed in processes of dynamic interaction. Based on the idea that communication constitutes organization (CCO), they "define CSR as communication and as a forum for debates over social norms and expectations attached to corporate responsibilities" (Schultz et al., 2013, p. 682). In this view, CSR communication plays an essential role as an intermediate between the social expectations held by the public and the corporation's CSR activities. Du and colleagues (2010) stated that minimizing stakeholders' skepticism and displaying intrinsic motives in CSR activities were key challenges of CSR communication.

Social media have become an integral part of the communication practices of corporations, including their use for displaying CSR activities. S. Y. Lee (2016) demonstrated that corporations with CSR messages on their Facebook pages had higher reputation scores than those without CSR messages on their pages. Similarly, Dutot et al. (2016) showed that CSR communication strategies through social media had a positive effect on the evaluation of those 
corporations on social media, so-called e-reputation. However, Kent and Taylor (2016) stated that the strength of social media to build up relations with stakeholders was not being fully realized by companies due to a unidirectional communication strategy. A recent study, for instance, pointed out that corporations used an informing strategy rather than an interacting strategy and that the public was less likely to engage with CSR messages on Facebook, which the authors concluded may have reflected public cynicism of CSR communication (Cho et al., 2017). The lack of interactivity in CSR communication by corporations on social media diagnosed in the literature (Etter, 2013; Kent \& Taylor, 2016) is astonishing insofar as interactivity has been previously shown to lead to reputational benefits. An experimental study by Eberle et al. (2013) showed that when stakeholders perceived CSR communication to be interactive, the message credibility and feelings of identification with a company were higher, which also led to a boost in corporate reputation.

Social media allow corporations to measure their interactions with the audience. By looking at how many reactions a post gets, organizations can evaluate how successful their communication is. On Facebook, the total number of reactions to content is usually referred to as engagement and includes all types of possible reactions (i.e., likes, shares, and comments). These metrics can be used as an indicator for how popular content was on Facebook and are also subsumed under the term popularity cues (Haim et al., 2018). Although it is contested if popularity cues can serve as an indicator for the approval or positive evaluation of content (and ultimately as a proxy for reputation), they are seen as an indicator for the relevance or salience of content on Facebook. Generally, engagement raises the reach of a post, but the algorithm of Facebook gives different weights to the single forms of engagement to determine what to display in the newsfeeds of users (C. Kim \& Yang, 2017). Research has pointed out that the different types of engagement represent different levels of interactivity (Ji et al., 2017). Likes are usually associated with a weak or shallow form of engagement. Comments are seen as a strong or profound type of engagement, whereas shares are located somewhere in-between weak and strong engagement. Although if and how different forms of engagement influence corporate reputation seem to be evident questions, empirical evidence is still rare. As an exception, Ji and colleagues (2017) analyzed the effects of different types of engagement on the corporate reputation of U.S. companies and showed that only comments had a significant effect on reputation. Comments with a negative tone led to more negative reputations, whereas positive comments led to more positive reputations.

By highlighting certain of its substantive attributes on Facebook, a corporation can try to set the agenda of the audience to influence the corporation's reputation. It seems unlikely that corporations will highlight negative aspects 
of CSR on their Facebook pages (i.e., link negative evaluative attributes to their CSR). Therefore, the hypothesis for a positive effect of CSR communication through Facebook on corporate reputation was tested. Our argument was that in the case of corporate social media activities, the corporate attributes were always linked to a positive evaluative attribute (i.e., a positive tone). We also tested a positive effect of engagement on reputation. We assumed that the more engagement a corporation received on its CSR-related Facebook posts, the higher the salience of the content in Facebook was. The expectation of salience on Facebook was therefore similar to our hypothesis for the salience of CSR in the news media. In other words, we examined if engaging the users on Facebook with CSR messages was successful in terms of reputation. For the effects of salience and the engagement of CSR on corporate Facebook pages, we thus formulated the following hypotheses:

Hypothesis 2.1: The higher the salience of the CSR on the Facebook pages of a corporation, the more positive its reputation will be.

Hypothesis 2.2: The more engagement a corporation receives on its CSRrelated posts on Facebook, the more positive its reputation will be.

\section{Method}

This study looked at the effects of salience and tone in media coverage of CSR on corporate reputation and the effects of CSR communication through Facebook on corporate reputation in Switzerland. This was accomplished by linking the data from a manual content analysis of news media, an automated content analysis of corporate Facebook posts, and a survey on corporate reputation. The research followed the tradition of linkage studies on agenda-setting effects in a business context as applied by Meijer and Kleinnijenhuis (2006a) and Carroll (2010). Similar designs have previously been applied for analyzing the effects of news media coverage and/or Facebook communication by companies on corporate reputation. For instance, Eisenegger and colleagues (2010) analyzed the effects of news media coverage on corporate reputation by combining annual news media coverage with a yearly reputation survey. Ji and colleagues (2017) examined the amount of Facebook engagement in a year before a reputation survey (in the form of the Forbes ranking of "America's Most Reputable Companies"). To study the effects of the salience of CSR messages on corporate Facebook pages on reputation, S. Y. Lee (2016) looked at all Facebook posts and media articles over a year and combined them with the survey data of the Reputation Institute's CSR ranking of 100 global companies. In particular, the approach by S. Y. Lee (2016) was very similar to our research design, even though that study examined just a single 
year. The study at hand was based on the further analysis of three existing individual data sets. The media data, the Facebook data, and the survey data were collected by using the same multi-dimensional concept to measure (media) reputation (Eisenegger \& Imhof, 2008; Vogler et al., 2016) making the linkage of the data sets valid. The survey was designed to replicate the definition of CSR used in the codebook of the content analysis, which was the initial study of the group. The codebook was also used to design and to validate the automated content analysis data (i.e., to decide whether a Facebook post concerned the CSR of the company or not).

\section{Sample and Data}

The sample for this study consisted of 68 Swiss corporations. The selection of the corporations was predetermined, as they were the corporations analyzed in the survey. It was extended over the years and included the 68 largest Swiss corporations in terms of turnover and employees through 2018. The sample considered multinational corporations like Nestlé (food), Novartis (pharmaceutical), and UBS (financial), as well as more nationally oriented medium-sized corporations like Migros (retail) and the Swiss Federal Railways (SBB). Switzerland is a valuable case because, despite being a small country, it has one of the most globalized (Gygli et al., 2019) and competitive economies, for instance, in terms of gross domestic product (GDP) per capita (The World Bank, 2018). As the structure of the economy was similar to other Western countries, we also assumed that our results would be applicable beyond Switzerland. However, one peculiarity of the Swiss case is its linguistic segmentation with four official languages (German, French, Italian, and Rumantsch). This study focused on the German- and Frenchspeaking parts of Switzerland as the inhabitants of the two regions represent $96 \%$ of the whole population (Federal Statistical Office, 2018).

\section{Data Set I: News Media}

The first data set included news media data for the 68 firms collected in the manual content analysis. The media sample (15 media outlets) consisted of different media types and included the subscription press (three outlets), the tabloid press (two outlets), the Sunday press (three outlets), weekly magazines (two outlets), and financial publications (three outlets), as well as the television (TV) news outlets of the Swiss public service broadcaster (two outlets). The study considered media outlets from the German- and Frenchspeaking parts of Switzerland. The media outlets were selected by the highest reach per type and printed editions of the news media were used due to accessibility over the examined period. In addition, it should be noted that almost 
all major online news sites were operated by legacy media corporations in Switzerland and, therefore, mostly used the same content.

For this study, news articles published between January 1, 2011, and December 31, 2017, were analyzed. A full sample was used, meaning that for the 15 media outlets, we analyzed every news article with at least one of the 68 corporations mentioned $(N=37,639)$. The sampling, therefore, considered unequal attention for corporations in different outlets. The news articles were accessed through the Swiss Media Database (SMD). The articles with at least one longer section (more than one third of the article measured in characters) on one of the corporations in the sample were further processed. This included articles that featured the corporation in general and articles about CSR. No restrictions were made concerning the article format or newspaper section in which it appeared. This meant that editorials and opinion pieces by journalists were also included, as they represented attempts to influence the attitudes toward corporations among the readership. The TV news programs were included in the analysis when the corporation was mentioned in the transcribed lead.

For each corporation, the tonality and the topical focus of the news articles were manually coded. For tone, a distinction was made between positive, negative, and neutral or balanced tonality, as this was common practice in communication research. We followed T. H. Lee and Riffe (2017), who analyzed tone in news media coverage of CSR and coded an article "as positive when CSR was referred to with positive emotional appeal [and] negative when CSR was referred to with negative emotional appeal" (p. 697). Accordingly, a positive or negative tone was coded when the corporation or its activities were explicitly praised or criticized in an article or when the corporation was featured in a positive or negative context, respectively. When positive and negative ratings occurred in the same article, the predominant tone was coded. If the positive and negative tone was used equally in the article, the parameter value "balanced" was coded. If no judgment at all was detected the parameter value "neutral" was coded. We coded the tone of coverage toward an individual corporation and not on the level of the whole article and, thus, only considered the text passages with references to the corporation under review. This meant that in the same article, two corporations with different tones could be coded. In a second step, we coded if the focus of the news article was on a corporation's CSR or other topics. The content analysis was designed to capture the same dimensions of CSR as in the reputation survey (see Table 1) and included articles that explicitly mentioned CSR practices as well as articles on corporate behavior with a social framing. Thus, the amount of CSR coverage and its tonality was determined for each corporation. The content analysis was conducted by trained coders 
with a good knowledge of both the German and French languages; this allowed them to code the news articles from both languages without translating the texts. Finally, the reliability of the manual coding was tested. Fleiss's kappa index for the interrater agreement was .70 for tonality and .73 for topical focus, indicating a substantial and, consequently, satisfactory agreement for the six members of the coding team (Landis \& Koch, 1977).

\section{Data Set 2: Reputation Survey}

The second data set included the data on the corporate reputation of the 68 Swiss firms collected through an online survey based on 3,500 interviews per year. The survey was conducted by the Growth from Knowledge (GFK) market research institute in Switzerland from 2011 to 2017 and is published once a year as the GFK Business Reflector. Their sample of respondents was representative of the public in the German- and French-speaking regions of Switzerland (sample breakdown: 49.7\% female; average age 42.5 years; average monthly household income category approx. US $\$ 4,500-U S \$ 7,000)$. Corporate reputation was measured using a Likert-type scale containing nine items in total. As we were interested in the agenda-setting effects of the coverage of CSR, data from the three items of the survey that measured social aspects of reputation were used in our study. The participants were asked to rate the corporations on a 7-point scale for each item. The items asked the respondents to identify how much they agreed with the statement that a corporation acts exemplary regarding social, economic, and environmental sustainability (see Table 1). Each of the three items were introduced with a short description and examples of corporate practices were provided. The participants were only asked about corporations they knew.

\section{Data Set 3: Corporate Facebook Pages}

The third data set consisted of social media data from the Facebook pages of the 68 analyzed firms. Facebook was selected because it was by far the most frequently used social network site in Switzerland (Reuters Institute for the Study of Journalism, 2019). All posts on the corporate Facebook page, which were published by the corporation between January 1, 2011 and December 31, 2017, were downloaded from Facebook using its API and the R package rfacebook in RStudio. Only the main corporate page was analyzed. We used the specific Swiss page when corporate pages in different languages were found. When specific Swiss pages were found in different languages (in German and French), we selected one based on the region in which the headquarters of the corporation was located. We did not code pages of corporate 
Table I. Questions in the Reputation Survey.

\begin{tabular}{|c|c|c|}
\hline $\begin{array}{l}\text { CSR } \\
\text { dimension }\end{array}$ & Introduction & $\begin{array}{l}\text { Agreement on a } \\
\text { 7-point scale }\end{array}$ \\
\hline Economic & $\begin{array}{l}\text { Economic sustainability means } \\
\text { the responsible use of financial } \\
\text { resources instead of short- } \\
\text { term profit maximization. It is } \\
\text { characterized by transparent } \\
\text { and truthful communication } \\
\text { and the maintenance of a good } \\
\text { corporate governance (e.g., } \\
\text { respect the law, no corruption). }\end{array}$ & $\begin{array}{l}\text { Compared with other } \\
\text { companies, the } \\
\text { company plays an } \\
\text { exemplary role in } \\
\text { the implementation } \\
\text { of economic } \\
\text { sustainability. }\end{array}$ \\
\hline Environmental & $\begin{array}{l}\text { Ecological sustainability is } \\
\text { characterized by the responsible } \\
\text { use of natural resources (e.g., } \\
\text { climate and environmental } \\
\text { protection; commitment to } \\
\text { renewable energies and energy } \\
\text { efficiency). }\end{array}$ & $\begin{array}{l}\text { Compared with other } \\
\text { companies, the } \\
\text { company plays an } \\
\text { exemplary role in } \\
\text { the implementation } \\
\text { of ecological } \\
\text { sustainability. }\end{array}$ \\
\hline Social & $\begin{array}{l}\text { Social sustainability is } \\
\text { characterized by regional } \\
\text { commitment (e.g., investment } \\
\text { in education, vocational } \\
\text { training, cultural sponsoring, job } \\
\text { creation), the ability to promote } \\
\text { the integration of people with } \\
\text { disabilities, support for the } \\
\text { equal treatment of men and } \\
\text { women and respect for other } \\
\text { cultures. }\end{array}$ & $\begin{array}{l}\text { Compared with other } \\
\text { companies, the } \\
\text { company plays an } \\
\text { exemplary role in the } \\
\text { implementation of } \\
\text { social sustainability }\end{array}$ \\
\hline
\end{tabular}

Note. Questions translated to English from German. CSR = corporate social responsibility.

divisions (e.g., the animal health division of a pharmaceutical corporation) or specific topical Facebook pages (e.g., about CSR), as we wanted a comparable sample for smaller and larger corporations as well as comparability between different sectors. This procedure led to a data set of 33,772 posts.

The Facebook posts were coded automatically. Posts referring to CSR were detected through a comparison with a list of 231 stemmed words that was compiled for the purposes of this article. The word list was developed using a data-driven approach. We computed lists with word and term frequencies (for single words, two-word terms, and three-word terms) using all Facebook posts and reviewed those lists to identify CSR-related words or 
concepts. The word list included general concepts (e.g., "CSR" and "sustainability") and terms referring to economic (e.g., "job security"), ecologic (e.g., "global warming"), and social (e.g., "fair trade") responsibility as well as industry-specific terms (e.g., "access to health-care" for the pharmaceutical industry). Due to the different languages used in the Facebook posts, the list took into consideration these words in the German, French, and common English terms used in both languages (e.g., fair trade or sustainability). As texts in the Facebook post are usually rather short, it was assumed that the posts containing at least one of the words from the list referred to CSR. To test the reliability of the automated content analysis, a random sample of 500 posts was manually coded. As a dichotomous variable was used, the search focused on finding true positives and true negatives (correctly classified posts of either category), as well as false positives and false negatives (falsely classified posts of either category). The precision (.86), recall (.77), and accuracy $(.97)$ scores confirmed that the analysis delivered satisfactory results (Powers, 2011).

\section{Measures}

Corporate reputation was measured through a survey with a Likert-type scale containing three items. The results were aggregated on the corporation level for each of the three items of the survey, and then an additive index for each corporation per year was calculated.

For the news media data and the Facebook data, all the measures were calculated for periods of 1 month, a quarter year, a half year, and a full year before the survey was conducted (in January). With this procedure, we tested which time lag provided the best goodness of fit.

The salience of CSR in the news media was measured by counting the number of media articles that focused on the CSR of a corporation. The salience of the media coverage that was not related to the CSR of a corporation was calculated as well and included in the model as an indicator for issues other than CSR. This procedure allowed for more robust results, as general media effects could be distinguished from CSR-specific effects.

The tone of CSR in the news media was calculated by using the reputation index (Eisenegger \& Imhof, 2008), which was designed for measuring media reputation. The index was calculated by subtracting the number of media articles with a negative tone from the number of media articles with a positive tone and dividing the result by the total number of media articles including those articles with a neutral or balanced tone. Hence, when multiplied by 100 , the index delivered values between -100 (only negative tone) and +100 (only positive tone). The index was calculated for each month 
and, subsequently, the scores were added for the different periods used in the models. The tone of the media coverage which was not related to the CSR of a corporation was calculated as well and included in the model as an indicator of tone in media coverage for topics other than CSR.

The salience of CSR on Facebook was measured by counting the number of CSR-related Facebook posts of a corporation. Some corporations did not have a Facebook page from 2011 onward, whereas 11 corporations were never on Facebook. For these cases, the number of Facebook posts referring to CSR was set to zero. The salience of Facebook posts that were not related to the CSR of a corporation was calculated as well and included in the model as an indicator for salience for topics other than CSR.

The engagement of the CSR posts on Facebook was measured by counting the likes, comments, and shares of all posts that were categorized as CSRrelated. The engagement of Facebook posts that were not related to the CSR of the corporation was calculated as well and included in the model as an indicator for engagement to topics other than CSR. For corporations with no Facebook pages, the values for both variables were set to zero. In addition, whether a corporation was present on Facebook with a page or not was coded for every year. This control variable was used as a proxy for the general adoption of social media practices.

Two important traits of companies, which were shown to have an effect on the CSR activities of corporations and their perception by stakeholders were company size (Kechiche \& Soparnot, 2012) and whether a company was in the business-to-consumer (B2C) or business-to-business (B2B) market (Homburg et al., 2013). We, therefore, included the relative size of the analyzed companies as well as their orientation toward the B2C market as control variables. First, the corporations were classified by their orientation to the B2C market, using a three-step scheme. Depending on the categorization of the industries, which were analyzed, the distinction was made between a low-B2C (predominantly B2B orientation: chemicals, pharmaceuticals, building, engineering; $36 \%$ of the total cases), medium-B2C (mixed B2B and B2C orientation: banks, insurance; $26 \%$ of the total cases), or high-B2C (predominantly $\mathrm{B} 2 \mathrm{C}$ orientation: retail, media, health services; $38 \%$ of the cases) market orientation. Second, the corporation size was also included using total turnover as a proxy and distinguishing between small (up to 5 billion Swiss Francs in turnover, which is approx. US\$5 billion; $21 \%$ of the total cases), medium (between 5 and 10 billion in turnover; $34 \%$ of the total cases), and large corporations (more than 10 billion in turnover; $45 \%$ of the total cases) in the sample (as a relative indicator for the sample, not with regard to the usual categorizations, e.g., of SMEs). 
The units of analysis were unique firm years. The three data sets for the 68 firms were matched and a final intersecting set of 380 firm years was obtained through the news media, social media, and survey data. As not all firms were part of the survey throughout the whole period, 96 of potentially 476 observations had to be omitted. When matching the data, the news media data and Facebook data were aggregated for the different periods and combined with the survey data collected in January of the subsequent year. For example, the news media and social media data for the full year of 2016 were combined with the survey data collected in January 2017.

To test the effects of the media coverage and Facebook communication on corporate reputation, regular ordinary least squares (OLS) regression models were used. As the time lag was an important factor when testing the agendasetting hypotheses (Roberts et al., 2002; Stone \& McCombs, 1981; Wanta \& $\mathrm{Hu}, 1994)$, different models were tested with time lags of 1 month, a quarter of a year, half a year, and one full year between the news media and social media data, accordingly. All the calculations were done in R Studio. The descriptive statistics for the data used for the full year are shown in Table 2.

\section{Results}

First, we tested the effects of the salience and tone in the news media coverage of CSR on corporate reputation with different time lags. The model which explained the most variance was the one using a full year of data (Table 3 shows for each time lag a model with and without the CSR-related news media and social media data). The goodness of fit for a full year of data was also supported by the lowest Bayesian information criterion (BIC). Thus, we treated the model with a full year of data (Model 2) as our main model in the following presentation of results. The model showed that the tone of the CSR media coverage had a positive effect on the reputation of a corporation $(\beta=.34 ; p<.001)$. Hence, hypothesis 1.1 was supported by the data. We also can see that the tone in the media coverage other than CSR had a positive effect on reputation as well $(\beta=.20 ; p<.001)$. The model also indicated that the salience of CSR in the news media had a significant positive effect on corporate reputation $(\beta=.31 ; p<.001)$, which was in line with our assumption for hypothesis 1.2. The more a corporation's CSR activities were mentioned in the news media, the more positive the evaluation of that corporation was by the public. This result was somewhat surprising because the tone of the media coverage of CSR was clearly negative $(M=-76.13$; see Table 2). The salience of the media coverage that was not related to CSR had no significant effect on reputation $(\beta=-.03 ; p=.731)$. Overall, significant effects of the news media coverage of corporate CSR 


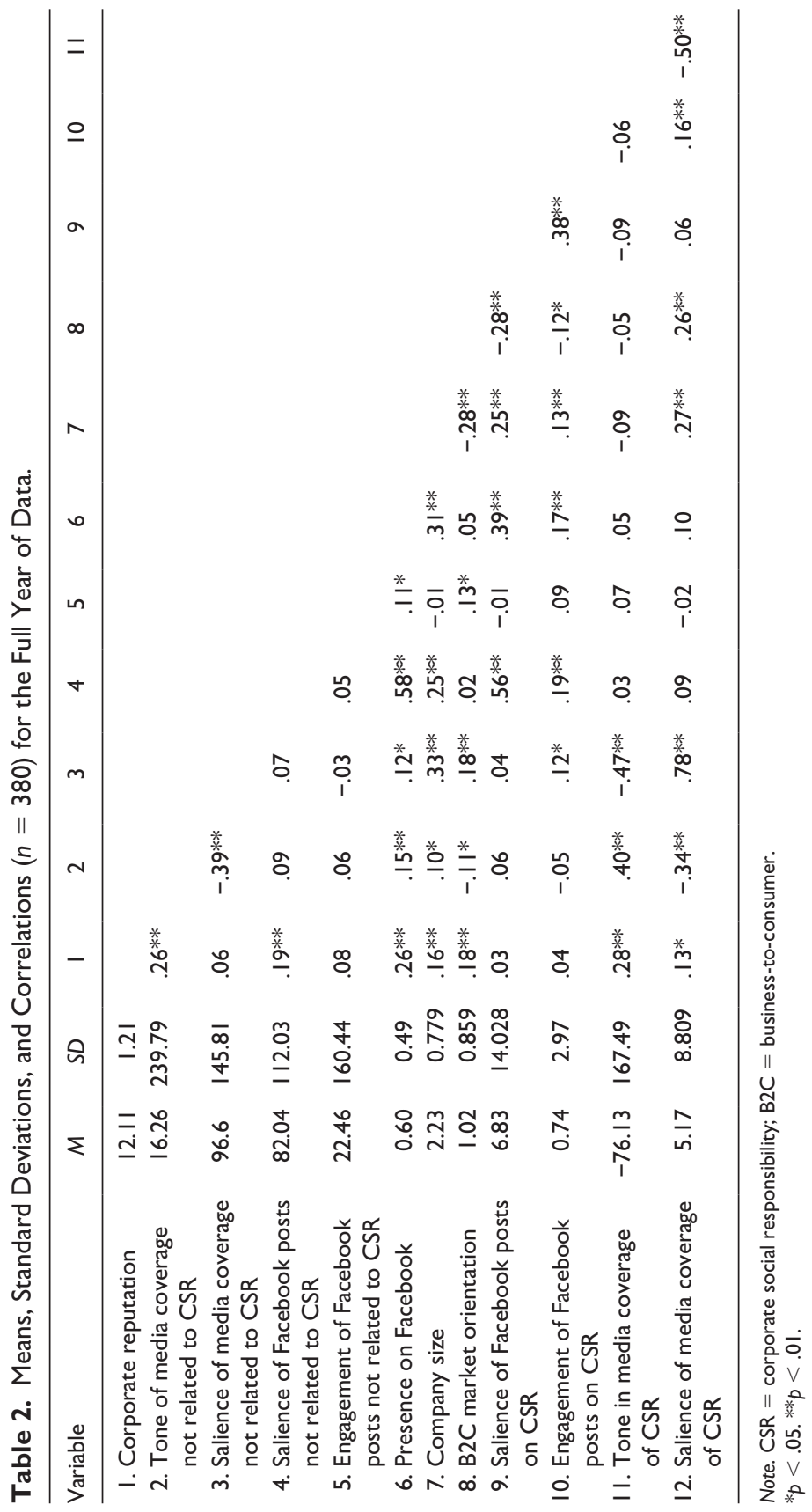




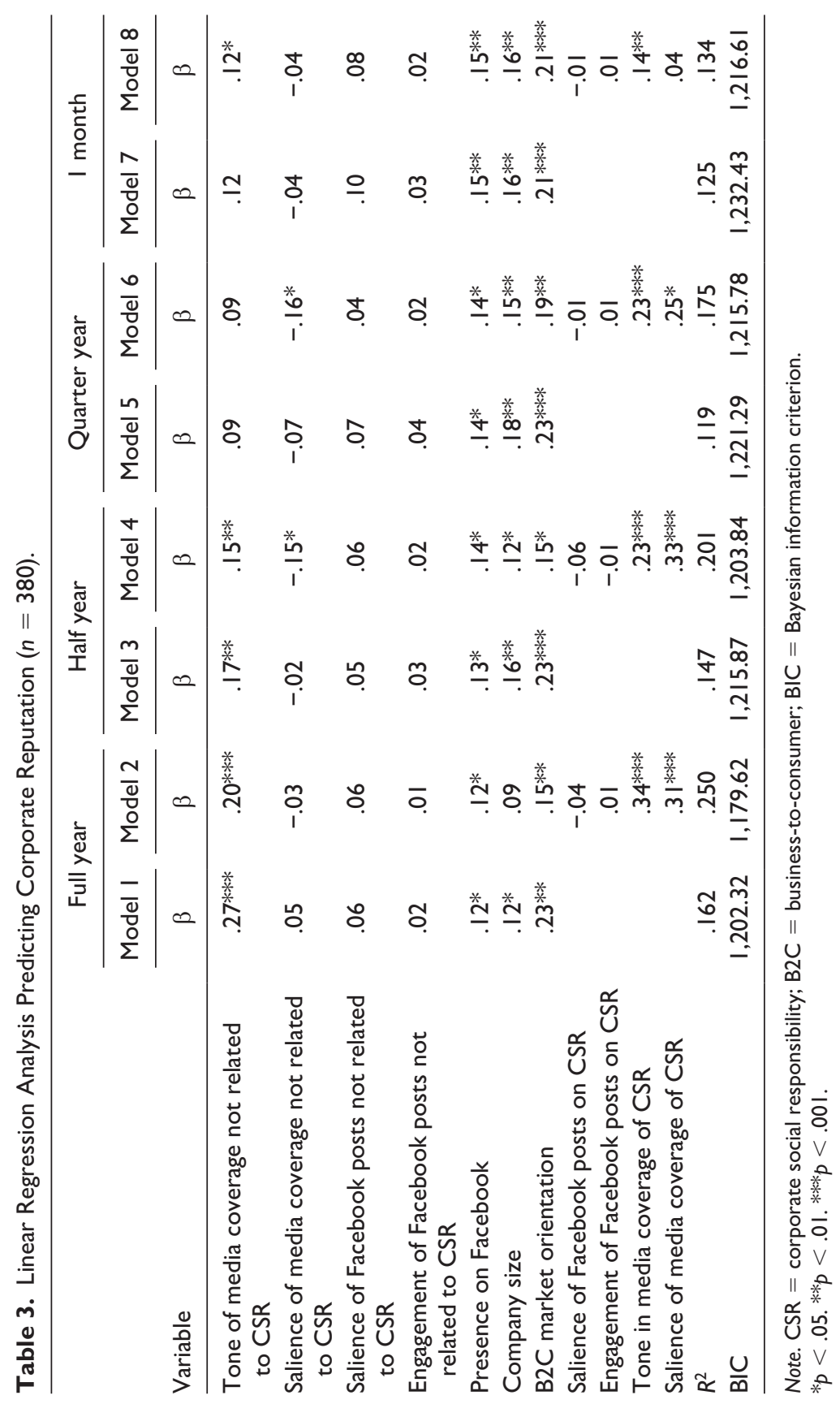


activities on the reputation of corporations were observed. When we looked at the four models with different time lags, the explanatory power of the CSR-related media data increased as the time lag lengthened (see Table 2). Nevertheless, the effects of tone in the CSR-related media coverage on reputation were observable for all the analyzed time lags, albeit to different extents. This result suggests that with regards to the evaluative dimension (i.e., tone) of the attribute CSR, the agenda-setting effects of news media on the public can be considered to build up over time. The same pattern was observed for the effect of the salience of the CSR-related news coverage on reputation, except for the shortest time lag of 1 month. When we looked at the effects of the news media coverage that was not related to CSR, we saw an increasing effect of tone on reputation as well. For the salience of a company in media coverage which was not related to CSR, we saw a different pattern. Significant negative effects were only found for time lags of half a year and a quarter year. These results suggest that salience in news media coverage, in general, does not lead to a better reputation.

Second, the effects of the salience of CSR in Facebook communication and user reactions to CSR posts on corporate reputation were tested with different time lags. The model showed that the salience of CSR on corporate Facebook pages did not lead to higher corporate reputation scores $(\beta=-.04$; $p=.548$ ). Consequently, hypothesis 2.1 was not confirmed. Hypothesis 2.2 must also be rejected as the engagement of CSR-related Facebook posts did not affect the reputation of a corporation $(\beta=.01 ; p=.842)$. Overall, no significant effects of social media data on corporate reputation were observed regardless of the time lag under review. Therefore, the explanatory power of the media data described above must have contributed to the news media coverage. However, the corporations with a presence on Facebook were evaluated more positively than the corporations without a Facebook page $(\beta=$ $.12 ; p=.002)$. The size of companies had no effect on corporate reputation $(\beta=$ $.09 ; p=.110$ ), whereas corporations with strong exposure to the $\mathrm{B} 2 \mathrm{C}$ market scored higher than companies with low exposure $(\beta=.15 ; p=.006)$.

As a robustness check, we analyzed a model for reputation with individual types of engagement as separate predictors and a full year of data. The overall results remained stable, as likes $(\beta=-.05 ; p=.382)$, shares $(\beta=.09$; $p=.234)$, and comments $(\beta=.04 ; p=.411)$ were not significantly related to reputation.

To further validate our analysis, we examined if the news media coverage and social media activities had an influence on the overall reputation rating, which was included in the survey (the overall rating of a firm on a 5-point scale). The effects of tone in the news media coverage of CSR also had a positive effect on overall reputation $(\beta=.25 ; p<.001)$, whereas the 
effect for salience on overall reputation was only just significant $(\beta=.14$; $p=.072)$. Although the variance explained by the data for the overall reputation rating $\left(R^{2}=.260\right)$ and the main CSR reputation model $\left(R^{2}=.250\right)$ were almost equal, the CSR-related media data clearly contributed to a smaller extent to the overall explanatory power of the model for overall reputation $(4.5 \%$ vs. $9.5 \%)$. The engagement $(\beta=-.01 ; p=.814)$ and salience $(\beta=$ $-.06 ; p=.337)$ of CSR on the corporate Facebook pages had no effect on the overall reputation rating. However, Facebook engagement to posts that were not related to CSR yielded positive effects on reputation $(\beta=.12 ; p=.006)$, indicating the effects of social media communication on reputation by issues other than CSR.

\section{Discussion}

The study at hand analyzed the effects of media coverage of CSR and CSR communication through Facebook on corporate reputation with a longitudinal design. It therefore contributes to the understanding of the impact of CSR communication in hybrid media systems. The results showed that the tone and salience of the news media coverage of CSR had a positive influence on corporate reputation, in other words, the way people evaluated a corporation. Hence, the results supported the hypotheses of second-level agenda-setting of the news media for the public (Carroll \& McCombs, 2003; McCombs et al., 1997). In contrast, there were no significant effects found for CSR communication through Facebook on corporate reputation. The findings suggest that the legacy media still were influential in the formation of corporate reputation, whereas corporate social media activities, at least through Facebook, did not seem to be very effective in building reputation. However, in hybrid media systems, the influence of the news media does not stop at the boundaries of social media, nor does the influence of corporate social media activities end at the gates of the news media. Instead, "the hybrid media system is built upon interactions of older and newer media logics" (Chadwick, 2017, p. 4). Although the questions of how CSR communication affects corporate reputation in the digital media environment and of how the different media logics interact in this process remain understudied, this study advances the empirical research and adds three main findings to the literature. Their theoretical and practical implications are discussed in the following.

The first finding of this study was that, as put forth in our first hypothesis, a more positive tone in news media coverage of CSR led to a better corporate reputation. This supports the findings of the study by Einwiller and colleagues (2010) which found a positive effect of tone in news coverage about social and environmental responsibility on reputation with a student population. However, 
this positive effect did not mean that the media coverage of CSR was a positive reputation driver for corporations. On the contrary, the data indicated that the tonality of the CSR media coverage was negative for most of the corporations. This finding confirms the results of previous studies that have shown a negative tone in news media coverage of CSR (Vogler \& Gisler, 2016). It also adds further insight to the discussion of CSR as a paradox (Morsing et al., 2008), as even though negativity was prevalent in the media coverage, the corporations with less negative (rather than more positive) media coverage were more likely to have good reputations. From a practitioner's perspective this is of relevance, as reputation was still strengthened even in the face of negative publicity. In other words, corporations did not get praised by the media for being socially responsible, but corporations that did not act responsibly were penalized with stronger negative publicity. This mirrors the expectations from the public, which considers corporations taking social responsibility to be the rule rather than an exception (Colleoni, 2013).

Our second finding adds to the complexity of the CSR paradox. As proposed in H1.2, the salience of the CSR coverage had a positive effect on reputation. Considering the positive effect of tone in the media coverage of CSR on corporate reputation, the results suggest that corporations should look for media attention directed toward their CSR even at the price of negative publicity. Corporations should try to raise the salience of their CSR in the news media coverage to prevent damage to their reputation and when they do so, they should do it in an extensive way. Given that taking responsibility is expected by the public and not something corporations can choose not to do, such a forward strategy seems more promising than trying to prevent negative media coverage. Communicating about CSR to the public (including the media) has therefore more to do with risk management than with building up a positive media image. Interestingly, when we look at the models representing different time lags, we see that salience, in comparison with tone, had a more long-term effect on reputation. The significance and strength of the effects of salience were shown to increase the larger the time lag was, whereas for tone, strong significant effects for all the time lags were found. This confirms previous research (Roberts et al., 2002) showing that agenda-setting effects of the media on the public were highly dependent on the timespan under review. From a practical perspective, this means that corporations should try to be continuously salient in media coverage with their CSR activities rather than seeking short-term gains in publicity and reputation with oneoff campaigns.

The third finding of this study was that, in contrast to the results for the news media coverage, no effect of CSR communication through Facebook on corporate reputation was found. Both hypotheses for the social media data were rejected as we could not find a positive effect of salience of CSR on 
corporate Facebook pages (H2.1) or user reactions to CSR-related Facebook posts (H2.2) on reputation. The study presented here, therefore, contests the results of previous research that found positive effects of corporate social media activities on reputation (Dutot et al., 2016; Ji et al., 2017; S. Y. Lee, 2016), which might be interpreted against the backdrop of fragmented audiences on social media (Feezell, 2018). The agenda-setting literature initially assumed effects of mass-media content on relatively large and homogenic audiences. Legacy news media still reach broad segments of the population in many countries, including Switzerland (Reuters Institute for the Study of Journalism, 2019). Content on social media, on the contrary, is supposed to reach specific audiences as a result of the distribution of content through algorithms. Agenda-setting effects emanating from social media could, thus, be considered to apply to very specific communities within the audience. If so, corporate communication on social media like Facebook might not be very popular in general, but will instead reach smaller segments of the audience (e.g., younger people). The effects of social media on audiences supposedly also depend on the platform under review. On Facebook, content distribution is strongly influenced by its algorithm and is oriented toward entertainment and a positive experience for the user (Bakshy et al., 2015). Twitter, as a counterexample, is designed as a news feed with less algorithmic content filtering and has a more news-oriented user population (Reuters Institute for the Study of Journalism, 2019). Further research, therefore, could look at the effects of corporate CSR communication through social media on specific populations that have high adoption rates of the social media platform under review. Interestingly, we found a positive effect on reputation for the control variable that measured the presence of a corporation on Facebook. This might indicate that the potential openness to dialogue in general (in contrast to corporations that did not have a Facebook page) was evaluated positively by the public and that corporations could benefit even more if they used social media in a dialogic way.

When it comes to the overall evaluation of the effects of social media communication of CSR on corporate reputation, this study certainly had its limitations as we only analyzed communication which was entirely controlled by the corporation itself. We tried to consider the effect of the virality of content quantitatively by looking at user reactions (likes) to CSR-related content. We did not, however, take into account further characteristics of the content, for instance, dialogic elements like questions. This study also provides no answers to the questions of how the content was discussed by users (e.g., tone in comments) or how other content on social media about a corporation's CSR produced by users influenced corporate reputation. The effects of social media on reputation might not be influenced as much by the communication from 
corporations but instead may be swayed more by what the users make of the content offered by corporations or by producing their own content.

Among the further limitations of this study, two specific aspects need to be pointed out. First, this examination focused on only one country. Although Switzerland certainly delivers a meaningful case due to its globally oriented economy, the perception of CSR by stakeholders (Chapple \& Moon, 2005; Golob \& Bartlett, 2007) as well as media coverage of CSR (T. H. Lee \& Riffe, 2017) have been shown to depend on the country under review. Further research could therefore look at the effects of news media coverage and social media communication related to CSR in different countries. In Switzerland, for example, news production is still dominated by legacy media corporations, whereas newer online players, like for instance, The Huffington Post or Buzzfeed, are rare (Reuters Institute for the Study of Journalism, 2019). It would therefore be fruitful to also reflect on different media systems when performing comparative research on the effects of CSR communication on reputation.

The second limitation was caused by the combination of the different data sources. Even though the three data sets used for this study contributed to a unique analysis, they were initially not designed to be integrated as they were used here. This led to some limitations in the overall design. As De Vreese and colleagues (2017) pointed out, the combination of media data and survey data would benefit from actual variables to measure the exposure to the (social) media content under review. This was not the case in this study. Follow-up studies could therefore consider measures regarding the exposure to the analyzed media channels.

Despite these limitations, this study provides new insights about the effects of news media coverage of CSR and CSR communication through social media on corporate reputation. When it comes to CSR, the news media, although challenged by digital communication channels, still played a crucial role in how the public evaluated corporations. In other words, the legacy news media were still able to set the public agenda when it came to CSRrelated topics. We did not find any effects of CSR communication through Facebook on corporate reputation. Although we mentioned a few plausible explanations, for instance, the fragmentation of audiences or selective exposure to news content on social media, still many open questions remain, such as what other factors are driving the results. Therefore, who sets the agenda in hybrid media systems when it comes to information about companies is a question which should be further explored.

\section{Declaration of Conflicting Interests}

The authors declared no potential conflicts of interest with respect to the research, authorship, and/or publication of this article. 


\section{Funding}

The authors received no financial support for the research, authorship, and/or publication of this article.

\section{ORCID iDs}

Daniel Vogler (iD https://orcid.org/0000-0002-0211-7574

Mark Eisenegger (iD https://orcid.org/0000-0002-4964-2528

\section{References}

Althaus, S. L., \& Tweksbury, D. (2002). Agenda setting and the "new" news: Patterns of issue importance among readers of the paper and online versions of the New York Times. Communication Research, 29, 180-207.

Bakshy, E., Messing, S., \& Adamic, L. A. (2015). Exposure to ideologically diverse news and opinion on Facebook. Science, 348(6239), 1130-1132.

Breitinger, D., \& Bonardi, J. P. (2017). Firms, breach of norms, and reputation damage. Business \& Society, 58, 1143-1176.

Brown, N., \& Deegan, C. (1998). The public disclosure of environmental performance information: A dual test of media agenda setting theory and legitimacy theory. Accounting and Business Research, 29, 21-41.

Byun, S. K., \& Oh, J. M. (2018). Local corporate social responsibility, media coverage, and shareholder value. Journal of Banking \& Finance, 87, 68-86.

Cahan, S. F., Chen, C., Chen, L., \& Nguyen, N. H. (2015). Corporate social responsibility and media coverage. Journal of Banking \& Finance, 59, 409-422.

Cardenal, A. S., Galais, C., \& Majó-Vázquez, S. (2018). Is Facebook eroding the public agenda? Evidence from survey and web-tracking data. International Journal of Public Opinion Research, 31, 589-608.

Carroll, C. E. (2010). Should firms circumvent or work through the news media? Public Relations Review, 36, 278-280.

Carroll, C. E., \& McCombs, M. E. (2003). Agenda-setting effects of business news on the public's images and opinions about major corporations. Corporate Reputation Review, 6, 36-46.

Chadwick, A. (2017). The hybrid media system (2nd ed.). Oxford University Press.

Chapple, W., \& Moon, J. (2005). Corporate social responsibility (CSR) in Asia: A seven-country study of CSR web site reporting. Business \& Society, 44, 415-441.

Cho, M., Furey, L. D., \& Mohr, T. (2017). Communicating corporate social responsibility on social media: Strategies, stakeholders, and public engagement on corporate Facebook. Business and Professional Communication Quarterly, 80, 52-69.

Colleoni, E. (2013). CSR communication strategies for organizational legitimacy in social media. Corporate Communications: An International Journal, 18, $228-248$.

Crane, A., \& Glozer, S. (2016). Researching corporate social responsibility communication: Themes, opportunities and challenges. Journal of Management Studies, $53,1223-1252$. 
Deephouse, D. L. (2000). Media reputation as a strategic resource: An integration of mass communication and resource-based theories. Journal of Management, 26, 1091-1112.

DeVito, M. A. (2017). From editors to algorithms: A values-based approach to understanding story selection in the Facebook news feed. Digital Journalism, 5 , 753-773.

De Vreese, C. H., Boukes, M., Schuck, A., Vliegenthart, R., Bos, L., \& Lelkes, Y. (2017). Linking survey and media content data: Opportunities, considerations, and pitfalls. Communication Methods and Measures, 11, 221-244.

Du, S., Bhattacharya, C. B., \& Sen, S. (2010). Maximizing business returns to corporate social responsibility (CSR): The role of CSR communication. International Journal of Management Reviews, 12, 8-19.

Dutot, V., Lacalle Galvez, E., \& Versailles, D. W. (2016). CSR communications strategies through social media and influence on e-reputation: An exploratory study. Management Decision, 54, 363-389.

Eberle, D., Berens, G., \& Li, T. (2013). The impact of interactive corporate social responsibility communication on corporate reputation. Journal of Business Ethics, 118, 731-746.

Einwiller, S. A., Carroll, C. E., \& Korn, K. (2010). Under what conditions do the news media influence corporate reputation? The roles of media dependency and need for orientation. Corporate Reputation Review, 12, 299-315.

Eisenegger, M., \& Imhof, K. (2008). The true, the good and the beautiful: Reputation management in the media society. In A. Zerfass, B. van Ruler, \& K. Sriramesh (Eds.), Public relations research (pp. 125-146). VS Verlag für Sozialwissenschaften.

Eisenegger, M., \& Schranz, M. (2011). Reputation management and corporate social responsibility. In Ø. Ihlen, J. L. Bartlett, \& S. May (Eds.), The handbook of communication and corporate social responsibility (pp. 128-146). Wiley-Blackwell.

Eisenegger, M., Schranz, M., \& Schneider, J. (2010). Corporate reputation and the news media in Switzerland. In C. E. Craig (Ed.), Corporate reputation and global news media: Case studies of agenda-setting (pp. 207-220). Routledge.

Esrock, S. L., \& Leichty, G. B. (1998). Social responsibility and corporate web pages: Self-presentation or agenda-setting? Public Relations Review, 24, 305-319.

Etter, M. (2013). Reasons for low levels of interactivity: (Non-) interactive CSR communication in Twitter. Public Relations Review, 39, 606-608.

Etter, M., Ravasi, D., \& Colleoni, E. (2019). Social media and the formation of organizational reputation. Academy of Management Review, 44, 28-52.

Federal Statistical Office. (2018). Ständige Wohnbevölkerung ab 15 Jahren nach Hauptsprachen [Permanent resident population aged $15+$ by main languages]. https://www.bfs.admin.ch/bfs/de/home/statistiken/bevoelkerung/sprachen-religionen/sprachen.html

Feezell, J. T. (2018). Agenda setting through social media: The importance of incidental news exposure and social filtering in the digital era. Political Research Quarterly, 71, 482-494. 
Fombrun, C. J., \& van Riel, C. (2003). Fame \& fortune: How successful companies build winning reputations. FT Press.

Golob, U., \& Bartlett, J. L. (2007). Communicating about corporate social responsibility: A comparative study of CSR reporting in Australia and Slovenia. Public Relations Review, 33, 1-9.

Grafström, M., \& Windell, K. J. (2011). The role of infomediaries: CSR in the business press during 2000-2009. Journal of Business Ethics, 103, 221-327.

Gygli, S., Haelg, F., Potrafke, N., \& Sturm, J. (2019). The KOF Globalisation IndexRevisited. The Review of International Organizations, 14, 543-574.

Haim, M., Kümpel, A. S., \& Brosius, H. B. (2018). Popularity cues in online media: A review of conceptualizations, operationalizations, and general effects. SCM: Studies in Communication and Media, 7, 186-207.

Hester, J. B., \& Gibson, R. (2003). The economy and second-level agenda setting: A time-series analysis of economic news and public opinion about the economy. Journalism \& Mass Communication Quarterly, 80, 73-90.

Homburg, C., Stierl, M., \& Bornemann, T. (2013). Corporate social responsibility in business-to-business markets: How organizational customers account for supplier corporate social responsibility engagement. Journal of Marketing, 77, 54-72.

Ji, Y. G., Li, C., North, M., \& Liu, J. (2017). Staking reputation on stakeholders: How does stakeholders' Facebook engagement help or ruin a company's reputation? Public Relations Review, 43, 201-210.

Kechiche, A., \& Soparnot, R. (2012). CSR within SMEs: Literature review. International Business Research, 5(7), 97-104.

Kent, M. L., \& Taylor, M. (2016). From homo economicus to homo dialogicus: Rethinking social media use in CSR communication. Public Relations Review, 42, 60-67.

Kim, C., \& Yang, S. U. (2017). Like, comment, and share on Facebook: How each behavior differs from the other. Public Relations Review, 43, 441-449.

Kim, Y., \& Woo, C. W. (2019). The buffering effects of CSR reputation in times of product-harm crisis. Corporate Communications: An International Journal, 24, 21-43.

Kiousis, S., Mitrook, M., Wu, X., \& Seltzer, T. (2006). First-and second-level agendabuilding and agenda-setting effects: Exploring the linkages among candidate news releases, media coverage, and public opinion. Journal of Public Relations Research, 18, 265-285.

Klein, J., \& Dawar, N. (2004). Corporate social responsibility and consumers' attributions and brand evaluations in a product-harm crisis. International Journal of Research in Marketing, 21, 203-217.

Landis, J. R., \& Koch, G. G. (1977). The measurement of observer agreement for categorical data. Biometrics, 33, 159-174.

Lee, B., Kim, J., \& Scheufele, D. A. (2015). Agenda setting in the internet age: The reciprocity between online searches and issue salience. International Journal of Public Opinion Research, 28, 440-455. 
Lee, S. Y. (2016). How can companies succeed in forming CSR reputation? Corporate Communications: An International Journal, 21, 435-449.

Lee, S. Y., \& Carroll, C. E. (2011). The emergence, variation, and evolution of corporate social responsibility in the public sphere, 1980-2004: The exposure of firms to public debate. Journal of Business Ethics, 104, 115-131.

Lee, T. H., \& Riffe, D. (2017). Business news framing of corporate social responsibility in the United States and the United Kingdom: Insights from the implicit and explicit CSR framework. Business \& Society, 58, 683-711.

Lim, J. (2006). A cross-lagged analysis of agenda setting among online news media. Journalism \& Mass Communication Quarterly, 83, 298-312.

Luo, J., Meier, S., \& Oberholzer-Gee, F. (2011). No news is good news: CSR strategy and newspaper coverage of negative firm events. Harvard Business School.

McCombs, M. E., Llamas, J. P., \& Lopez-Escobar, E. (1997). Candidate images in Spanish elections: Second-level agenda-setting effects. Journalism \& Mass Communication Quarterly, 74, 703-717.

McCombs, M. E., \& Shaw, B. L. (1972). The agenda-setting function of mass media. The Public Opinion Quarterly, 36, 176-187.

Meijer, M., \& Kleinnijenhuis, J. (2006a). Issue news and corporate reputation: Applying the theories of agenda setting and issue ownership in the field of business communication. Journal of Communication, 56, 543-559.

Meijer, M., \& Kleinnijenhuis, J. (2006b). News and corporate reputation: Empirical findings from the Netherlands. Public Relations Review, 32, 341-348.

Meraz, S. (2009). Is there an elite hold? Traditional media to social media agenda setting influence in blog networks. Journal of Computer-Mediated Communication, 14, 682-707.

Minor, D., \& Morgan, J. (2011). CSR as reputation insurance: Primum non nocere. California Management Review, 53(3), 40-59.

Morsing, M., \& Schultz, M. (2006). Corporate social responsibility communication: Stakeholder information, response and involvement strategies. Business Ethics: A European Review, 15, 323-338.

Morsing, M., Schultz, M., \& Nielsen, K. U. (2008). The catch 22 of communication CSR: Findings from Danish study. Journal of Marketing Communication, 14(2), 97-111.

Neuman, W. R., Guggenheim, L., Jang, S. M., \& Bae, S. Y. (2014). The dynamics of public attention: Agenda-setting theory meets big data. Journal of Communication, 64, 193-214.

Palmgreen, P., \& Clarke, P. (1977). Agenda-setting with local and national issues. Communication Research, 4, 435-452.

Peloza, J., \& Shang, J. (2011). How can corporate social responsibility activities create value for stakeholders? A systematic review. Journal of the Academy of Marketing Science, 39, 117-135.

Pérez, A. (2015). Corporate reputation and CSR reporting to stakeholders: Gaps in the literature and future lines of research. Corporate Communications: An International Journal, 20, 11-29. 
Pollach, I. (2013). Corporate environmental reporting and news coverage of environmental issues: An agenda-setting perspective. Business Strategy and the Environment, 23(5), 349-360.

Powers, D. M. W. (2011). Evaluation: From precision, recall and F-measure to ROC, informedness, markedness and correlation. Journal of Machine Learning Technologies, 2, 37-63.

Ragas, M. W. (2013). Agenda-building and agenda-setting theory: Which companies we think about and how we think about them. In C. E. Carroll (Ed.), The handbook of communication and corporate reputation (pp. 153-165). John Wiley.

Reputation Institute. (2017). Closing the gap between actual and perceived corporate social responsibility. https://www.reputationinstitute.com/the-gap-betweenactual-and-perceived-csr.aspx

Reuters Institute for the Study of Journalism. (2019). Reuters Institute digital news report 2019. https://reutersinstitute.politics.ox.ac.uk/sites/default/files/inlinefiles/DNR 2019 FINAL.pdf

Roberts, M., Wanta, W., \& Dzwo, T. (2002). Agenda setting and issue salience online. Communication Research, 29, 452-465.

Sayre, B., Bode, L., Shah, D., Wilcox, D., \& Shah, C. (2010). Agenda setting in a digital age: Tracking attention to California Proposition 8 in social media, online news and conventional news. Policy \& Internet, 2(2), 7-32.

Schnietz, K. E., \& Epstein, M. J. (2005). Exploring the financial value of a reputation for corporate social responsibility during a crisis. Corporate Reputation Review, 7, 327-345.

Schoeneborn, D., Morsing, M., \& Crane, A. (2019). Formative perspectives on the relation between CSR communication and CSR practices: Pathways for walking, talking, and $\mathrm{t}(\mathrm{w})$ alking. Business \& Society, 59, 5-33.

Schultz, F., Castelló, I., \& Morsing, M. (2013). The construction of corporate social responsibility in network societies: A communication view. Journal of Business Ethics, 115, 681-692.

Schultz, F., \& Wehmeier, S. (2010). Institutionalization of corporate social responsibility within corporate communications: Combining institutional, sensemaking and communication perspectives. Corporate Communications: An International Journal, 15, 9-29.

Stone, G. C., \& McCombs, M. (1981). Tracing the time lag in agenda-setting. Journalism Quarterly, 58, 51-55.

Takeshita, T. (2006). Current critical problems in agenda-setting research. International Journal of Public Opinion Research, 18, 275-296.

Tam, L. (2019). Share of voices in corporate social responsibility (CSR) news: A comparison of sources used in press releases and news coverage. Corporate Communications: An International Journal, 24, 128-142.

Vogler, D., \& Gisler, A. (2016). The effect of CSR on the media reputation of the Swiss banking industry before and after the financial crisis 2008. $u w f$ UmweltWirtschaftsForum, 24(2), 201-206. 
Vogler, D., Schranz, M., \& Eisenegger, M. (2016). Stakeholder group influence on media reputation in crisis periods. Corporate Communications: An International Journal, 21, 322-332.

Wallace, J. (2018). Modeling contemporary gatekeeping: The rise of individuals, algorithms and platforms in digital news dissemination. Digital Journalism, 6, 274-293.

Wallsten, K. (2007). Agenda setting and the blogosphere: An analysis of the relationship between mainstream media and political blogs. Review of Policy Research, 24, 567-587.

Wanta, W., \& Hu, Y. (1994). Time-lag differences in the agenda-setting process: An examination of five news media. International Journal of Public Opinion Research, 6, 225-240.

Williams, B. A., \& Delli Carpini, M. X. (2004). Monica and Bill all the time and everywhere: The collapse of gatekeeping and agenda setting in the new media environment. American Behavioral Scientist, 47, 1208-1230.

Wirth, W., Matthes, J., Schemer, C., Wettstein, M., Friemel, T., Hänggli, R., \& Siegert, G. (2010). Agenda building and setting in a referendum campaign: Investigating the flow of arguments among campaigners, the media, and the public. Journalism \& Mass Communication Quarterly, 87, 328-345.

The World Bank. (2018). Data bank. World Development Indicators. https://data. worldbank.org/indicator/ny.gdp.pcap.cd

\section{Author Biographies}

Daniel Vogler is the research director of the Research Center for the Public Sphere and Society (fög) at the University of Zurich and research associate at the Department of Communication and Media Research (IKMZ) at the University of Zurich. His research focuses on public relations, journalism, and online communication. He has published in such journals as Corporate Communications: An International Journal, International Journal of Communication, and Journal of Communication Management.

Mark Eisenegger is a full professor of Communication Science at the Department of Communication and Media Research (IKMZ) at the University of Zurich. He is also the director of the Research Center for the Public Sphere and Society (fög) at the University of Zurich. His research focuses on the digital transformation of the public sphere and organizational communication. He has published in such journals as Corporate Communications: An International Journal, International Journal of Communication, and the Journal of Information Policy. 